\title{
MAQUIAVEL E A EDUCAÇÃO: A FORMAÇÃO DO BOM CIDADÃO
}

José Luiz AMES ${ }^{1}$

- RESUMO: Maquiavel é popularmente conhecido por uma teoria política associada ao seu nome: "maquiavelismo". O artigo realiza um esforço inicial para afastar o pensamento maquiaveliano de semelhante concepção. Em seguida, faz uma análise detalhada de todas as ocorrências do termo "educação", num total de onze, na sua obra. A hipótese que orienta nossa reflexão é de que a educação é pensada por Maquiavel como uma força destinada a controlar a desordem inerente ao movimento tanto do desejo quanto da natureza impedindo os efeitos deletérios daquele sobre a vida política. Graças à educação, o homem é capaz de conhecer a "natureza das coisas", isto é, saber o que as coisas são "desde sempre" e, desta maneira, antecipar-se ao "curso das coisas ordenado pelos céus". Por fim, procuramos mostrar que, para Maquiavel, a educação possibilita moldar o comportamento dos indivíduos de tal modo que é possível redirecionar o curso das coisas para uma ordem coerente com o bem coletivo.

- PALAVRAS-CHAVE: Maquiavel; educação; cidadania; política; ética.

Acompanha Maquiavel a (má) fama de ser pai de uma doutrina política que carrega seu nome: "Maquiavelismo". Esta doutrina indica geralmente uma ação cínica da parte daquele que, sem qualquer escrúpulo moral, persegue unicamente os próprios interesses egoísticos e abomináveis. Por esta ótica, Maquiavel seria um diabólico especialista da trapaça, um conselheiro de tiranos que querem engrandecer a si próprios à custa do bem comum dos homens por eles governados, um inimigo da raça humana, de toda piedade e religião, o instrumento de Satanás. O que um pensador identificado com semelhantes ideias poderia ter a dizer sobre educação?

1 Doutor em filosofia e professor associado do Departamento de Filosofia da Universidade Estadual do Oeste do Paraná ( UNIOESTE). Artigo recebido em 10/08 e aprovado em 12/08. 
Talvez seja preciso começar desfazendo esta má-fama que acompanha o nome de Maquiavel. É o caminho que seguiram muitos intérpretes. Didática e esquematicamente podemos dividi-los em dois grupos principais: de um lado aqueles que recusam a acusação por ver no florentino o autor de uma moral política severa para com a conduta política; de outro os que excluem de seu pensamento toda referência moral. Como exemplo da primeira perspectiva podemos citar a obra de Leonard von Muralt; da segunda, o trabalho de Ernst Cassirer.

Segundo Leonard von Muralt (1945, p. 67-81), Maquiavel é o adversário mais declarado do maquiavelismo. Segundo ele, não apenas seria um equívoco chamar Maquiavel de pai da mentira, como o florentino desaconselharia abertamente a mentir, porque não ignoraria que a honestidade é a melhor diplomacia. Maquiavel de forma alguma poderia ser tido como defensor da tirania, pois acolheria como forma de governo ideal a república fundada sobre a justiça, defendida por um exército constituído pelos próprios cidadãos e regida pela lei. Ainda segundo von Muralt, Maquiavel não compartilharia uma ideia de virtù como pura concentração de força e astúcia, mas a subordinaria à bontà, à honestidade do cidadão. Igualmente, Maquiavel não desprezaria a religião, particularmente o cristianismo, pois a defenderia como componente imprescindível do Estado. Estaria longe de todo historicismo e relativismo moral, pois partilharia a ideia da existência de uma escala absoluta de valores. Enfim, o Estado desejado por Maquiavel seria um rechte Staat: uma república livre, igualitária e pacífica.

No extremo oposto dos defensores de Maquiavel contra a acusação de maquiavelismo estão aqueles que opõem ao destruidor da ética o técnico da ação, alguém que concebe a política como uma atividade situada fora do domínio da moral, "acima do bem e do mal". Ernst Cassirer é, talvez, o mais conhecido dos defensores da tese de que Maquiavel é um técnico frio sem compromissos éticos ou políticos, um analista político objetivo, um cientista moralmente neutro e desinteressado quanto ao uso de suas descobertas "técnicas", que podem servir tanto a libertadores quanto a déspotas. ${ }^{2}$ Para Cassirer, a atividade política se ajustaria tanto ao Estado legal quanto ao ilegal, não sendo imoral, nem moral. Ele simplesmente ofereceria a todos os soberanos, reais ou virtuais, legítimos ou ilegítimos, conselhos eficazes para estabelecer e manter o seu poder, para evitar as discórdias internas, para prevenir ou para triunfar sobre as conspirações. Maquiavel é apresen-

2 Outro autor de grande repercussão que compartilha semelhante ideia é Augustin Renaudet (1943, p. 216), para o qual O Príncipe é "[...] acima de tudo um livro de ciência. [...] Ele descreve a criação e o crescimento de um Estado principesco, como um físico ou um biólogo expõem um conjunto de fatos regidos pelas leis da natureza". 
tado como o profeta da técnica em política, o mestre do realismo amoral. O campo de preocupação de Maquiavel não seria a política em sentido normativo, e sim esta atividade humana no sentido puramente descritivo, de modo semelhante a um cientista social que descreve como funcionam de fato as realidades políticas. Indignar-se diante dos meios indicados para a fundação e conservação de Estados enunciados por Maquiavel estaria tão fora de lugar como repreender um físico que enuncia o valor de uma constante.

O quadro deixa perceber que a interpretação de Maquiavel como "maquiavélico" está longe de ser uma evidência. Tanto os que afastam sua obra de quaisquer preocupações éticas como os que a interpretam a partir desta chave destituem de legitimidade a leitura do maquiavelismo. Às duas correntes extremas poderíamos acrescentar ainda aquela que, em lugar de ler Maquiavel por estes registros, o liga às fontes do republicanismo clássico: um pensador que defende a subordinação dos interesses particulares ao bem púbico; que combate a tirania; que alimenta o desejo de atingir a glória e a honra para si e para a pátria. Entre os inúmeros intérpretes contemporâneos do chamado "republicanismo neo-romano", podemos destacar Quentin Skinner (1996).

Uma vez afastado o "fantasma" do maquiavelismo do coração do pensamento de Maquiavel, resta possível considerar pertinente que o florentino possa ter algo a dizer sobre educação. Por certo é uma perspectiva muito singular que nada tem em comum com uma "teoria pedagógica" à semelhança do que foi comum a outros pensadores do mesmo período influenciados pelo Renascimento. Uma constatação inicial, frustrante, é a quase completa ausência de publicações dedicadas especificamente ao tema. No máximo encontramos abordagens que tangenciam a questão, focadas particularmente na importância da educação cívica para a constituição de um Estado estável, como é o caso de Skinner.

A escassez de estudos dedicados diretamente ao tema da educação em Maquiavel talvez deva ser tributada ao próprio autor: o termo educazione está ausente de dois trabalhos célebres, O Príncipe e Histórias florentinas. Já nos Discursos sobre a primeira década de Tito Lívio ela ocorre nove vezes, uma vez em Da arte da guerra e uma vez em Os Capítulos - Da Ambição. No presente estudo faremos uma análise destas onze ocorrências do termo na sua obra.

Levando em consideração o conjunto de suas referências à educação, seria possível identificar algo que pudesse ser uma "ideia diretriz"? Parecenos que o sentido real do termo educazione é captado a partir do princípio essencial da visão maquiaveliana de que a totalidade das coisas, naturais e humanas, é atravessada por um movimento incessante: "estando as coisas humanas sempre em movimento, ou sobem ou descem" (Discursos Intro- 
dução, II). ${ }^{3}$ Para o florentino, os homens e as coisas são instáveis, o desejo não deixa nada em repouso. Cabe, pois, um breve exame deste aspecto.

Para Maquiavel, o homem é determinado, fundamentalmente, pelo dinamismo da necessidade natural do desejo que o impulsiona incansavelmente e sem qualquer controle interno. A característica essencial do desejo humano é sua imoderação e desmedida. O homem é insaciável, seu desejo se dirige a tudo e sem qualquer controle interno. Em duas passagens, e praticamente com as mesmas palavras, Maquiavel expressa esta ideia: "sendo os apetites humanos insaciáveis, porque tendo por natureza o poder e a vontade de desejar qualquer coisa e por fortuna o poder de conseguir delas pouco, resulta continuamente um descontentamento no espírito humano, e um tédio das coisas que se possuem" (Discursos II, Introdução). ${ }^{4}$

O desejo se mostra, assim, a mola propulsora de todas as ações humanas. Não há desejo que não seja ativo e não há ação que não seja desejada. Mesmo quando o homem parece estar agindo contra seu desejo como, por exemplo, quando entrega um bem sob ameaça, ainda assim é por um desejo que age: o desejo de preservar sua vida, que se impõe ao desejo de conservar seus bens.

O desejo, considerado em si mesmo, é potência presente. É sempre num agora e aqui que o homem deseja. Maquiavel aponta para a ambivalência inerente à própria estrutura do desejo: ele é potência, mas limitada; ou seja, "a natureza criou os homens de maneira que podem desejar qualquer coisa, mas não podem conseguir qualquer coisa" (Discursos I, 37). Desejamos tudo, porque não somos tudo, não somos Deus. Sempre nos falta algo. Assim, o desejo, como força finita, é vivido como carência infinita. Ele nada mais é do que a afirmação de uma força em seu esforço sem fim para durar e aumentar.

O desejo é sempre particular. É sempre um sujeito individual que deseja algo para si. É, pois, singular e tem em vista o interesse próprio. É devido a esta característica que o desejo opõe os homens entre si. Quer dizer, pelo fato de o desejo ser singular, ao satisfazê-lo se contrapõe ao desejo do outro. Assim, os homens se opõem entre si não porque são malvados, mas porque são rivais na consumação de seus desejos.

3 Indicaremos as referências diretamente no corpo do texto, citando a obra pela primeira palavra do título e a remissão à parte da obra em romano e ao capítulo em arábico.

4 A outra passagem a que nos referimos é a seguinte: "A natureza criou os homens de maneira que podem desejar qualquer coisa, mas não podem conseguir qualquer coisa; desse modo, sendo sempre maior o desejo do que a potência de conquistar resulta disso o descontentamento do que se possui e a insatisfação em relação a isso. Disso nasce a variação de suas fortunas" (Discursos I, 37). 
Além do fato do desejo, que coloca todas as coisas em contínuo movimento, notadamente aquelas que dependem da vontade humana, deve-se ter em conta que todos os corpos cumprem um ciclo vital que é determinado pela própria natureza. O ciclo vital da natureza é marcado pelas etapas pelas quais todo ser vivo passa: nascimento, desenvolvimento e morte. É assim na natureza vegetal e animal (corpos simples), mas é também do mesmo modo nos Estados e religiões (corpos mistos). Ambos, corpos simples e mistos, são regulados pelos mesmos fenômenos de saúde e doença. A "natureza" do corpo misto é semelhante a do corpo simples. "Natureza" para Maquiavel é princípio de movimento que emerge do fundo de cada ser: "a natureza, como os corpos simples, quando acumularam muita matéria supérflua, se move muitas vezes por si mesma e se purga dela, o que lhes devolve a saúde; [o mesmo sucede] neste corpo misto da geração humana" (Discursos II,5). A natureza como princípio do movimento entendido como variação é para Maquiavel uma verdadeira lei objetiva, "lei natural". Lei natural é "o curso das coisas ordenadas pelos céus" (Discursos III,1). O termo final necessário do curso das coisas é a degeneração: "nada é mais certo do que o fato de que todas as coisas do mundo têm um final" (Discursos III,1).

Temos, pois, duas ordens de movimento: aquele que emerge do desejo e o que brota da natureza. Ambos, caso se permita que sigam livremente o curso que lhes é próprio, levam à desordem: o desejo, não submetido ao controle da lei, causa a anarquia e a dissolução do vivere civile; a natureza, que segue um movimento "por necessidade", culmina na degradação definitiva de toda ordem visível.

A educação é pensada por Maquiavel como uma força destinada a controlar a desordem inerente ao movimento tanto do desejo quanto da natureza. Evidentemente, a educação não é capaz de conter o movimento. Afinal de contas, tanto o desejo quanto a natureza são propulsores de um movimento "necessário", quer dizer, inerente às coisas. Apesar disso, pode "ordená-lo" impedindo os efeitos deletérios à vida política. Graças à educação, o homem é capaz de conhecer a "natureza das coisas", isto é, saber o que as coisas são "desde sempre". Bem entendido, este conhecimento não é, para Maquiavel, uma descoberta da "essência" metafísica das coisas, e sim um saber sobre aquilo que há de permanente e regular no modo como elas ocorrem. Entendendo o movimento das coisas, o sujeito torna-se capaz de se antecipar ao "curso das coisas ordenado pelos céus". Significa dizer, pela educação o homem será capaz de manejar a realidade com maior facilidade para controlá-la e dirigir seus esforços no sentido de obter êxito. Por fim, a educação possibilita moldar o comportamento dos indivíduos de tal modo que o curso das coisas se redirecione para uma ordem coerente com o bem coletivo. Na sequência faremos um exame das passagens nas quais Maquiavel refere-se à educação para mostrar como ela promove esse conhecimento. 
Comecemos pelos Discursos, obra na qual Maquiavel menciona o maior número de vezes a educazione. A primeira referência pode ser encontrada já na Introdução ao Livro I. Lamentado a negligência dos contemporâneos de servir-se das lições da história para a condução política, diz estar convencido de que a causa dessa falha

[...] procede menos da fraqueza (debolezza) à qual a educazione atual conduziu o mundo, ou do mal que um ambicioso ócio causou às muitas províncias e cidades cristãs, do que não haver um verdadeiro conhecimento da história e de não extrair dela, ao lê-la, seu sentido, nem experimentar do sabor que encerra. (Discursos I, Introdução)

Fica evidente a intenção de contrapor a uma leitura meramente contemplativa uma interpretação ativa e utilitária, a qual visa extrair lições do passado para aplicá-las ao presente e futuro, convertendo a história em instrumento de educação. Se os homens de Estado não se utilizam da história como mestra da vida, isso não se deve tanto a uma fraqueza da educação do que ao fato de enxergar na história nada mais do que um conjunto de fábulas maravilhosas. Somente um olhar guiado pela verdade poderá desvelar o sentido do útil. A culpa maior da educação reside em outra coisa: haver conduzido o mundo atual à "fraqueza" (debolezza). Esta fraqueza está associada ao "ócio". O ócio aparece em Maquiavel em três acepções distintas: como inércia (ou preguiça) que se opõe à energia (ou virtù); como licenciosidade decorrente da ausência de controle por oposição à força disciplinadora da necessidade; como a situação que oferece um excesso de possibilidades de escolha: o ócio torna os homens mais lentos em lhes oferecer uma quantidade de alternativas. A concepção maquiaveliana do ócio revela a influência que exerceu sobre ele o humanismo renascentista, que atribui um lugar secundário à contemplação (otium) e subordinado ao ideal da vida ativa (negotium). Na avaliação de Maquiavel, o ócio degenera os costumes e corrompe a vida política: "as razões da desunião das repúblicas, na maioria das vezes, são o ócio e a paz" (Discursos II,25).

A crítica à educação como promotora da debolezza será retomada por Maquiavel em outros dois momentos, sempre utilizando o mesmo termo para se referir aos efeitos produzidos pela educação nos seus dias. Assim, referindo-se aos seus contemporâneos, afirma: "Mas a fraqueza (debolezza) dos homens de hoje, causada por sua fraca (debole) educazione e da pouca informação sobre as coisas, faz com que julguem os julgamentos dos antigos em parte desumanos, em parte impossíveis" (Discursos III, 27).

Assim como no fragmento anterior, também neste Maquiavel aborda a negligência dos contemporâneos de servir-se do ensinamento dos antigos para orientar as ações políticas. Na passagem em questão, Maquiavel dis- 
cute em torno da estratégia mais adequada para a unificação de um Estado dividido por facções rivais e aponta três alternativas: exterminar os culpados; bani-los; ou fazer as pazes com eles. Mostra que, embora a segunda alternativa por vezes funcione (como no caso dos florentinos em relação à Pisa), o meio mais seguro é o primeiro. Por que, então, não é adotado presentemente pelos chefes políticos? A resposta está na passagem citada: o motivo está na debolezza dos homens e na debole educazione que faz com que eles considerem as lições dos antigos desumanas ou impossíveis.

A crítica maquiaveliana à educação dos modernos tem seu contraponto positivo no exemplo dos antigos romanos e é por esta razão que propõe a imitação destes como forma de recuperar a virtù perdida pela corrupção presente. De que "virtude" se trata? Trata-se da virtude cívica que corresponde não a uma qualidade moral do indivíduo, e sim à virtude cívica ligada à "[...] concepção clássica dos romanos que a identifica com qualidades tais como: simplicidade de costumes, moderação, coragem, patriotismo, disponibilidade a sacrificar-se pelo bem comum, etc." (PINZANI, 2006, p.97). Estas qualidades não são apropriadas ao aperfeiçoamento moral dos indivíduos, como é o caso na virtude cristã, e sim estão destinadas a formar um bom cidadão. Não formam um "homem bom", mas um "bom cidadão". Quais qualidades identificam um "bom cidadão" na concepção maquiaveliana? Em primeiro lugar, a subordinação do bem particular ao bem comum. A virtude cívica desenvolve nos homens à capacidade de servir a pátria até com a própria vida, se necessário. Em segundo lugar, à coragem: o cidadão dotado de virtude cívica não teme defender a cidade ou expandir seus domínios sempre que isso se mostra necessário para conservá-la livre. Em terceiro lugar, à religiosidade: o bom cidadão é temente a Deus o que faz com que respeite os preceitos legais como se fossem mandamentos divinos. Em quarto lugar, à repugna ao ócio: o ideal de homem está vinculado à vida ativa e produtiva e não à contemplação e meditação, como é para o pensamento medieval-cristão.

A virtude cívica está intrinsecamente vinculada à educação. Não são qualidades que o homem porta por nascimento, mas são cultivadas nele através de um processo formativo. A educação pode tanto formar homens dotados das virtudes imprescindíveis para ser um bom cidadão quanto pode fazer dele uma pessoa fraca e arrogante. De alguma maneira os homens são o que a educação fez deles. Ela molda o modo de ser dos homens:

Tornar-se insolente na boa fortuna e desprezível na má nasce do modo do teu comportamento e da educazione na qual foste criado; esta, se é fraca (debole) e vã, te torna semelhante a ela; se é oposta, te torna também de outro tipo e, tornando-te melhor conhecedor do mundo, te fará alegrar-te menos do bem e entristecer-te menos do mal. (Discursos III,31) 
A maneira como o homem encara o mundo é desenvolvido por meio da educação. Maquiavel recusa todo determinismo natural ou de qualquer outro gênero. Cada um é aquilo que a educação fez dele. Ser "fraco" ou ser "forte", isto é, ser determinado e corajoso ou débil e resignado, não é uma determinação natural, mas cultural; não é uma qualidade inata, mas cultivada. O fragmento não deixa lugar a dúvidas: a educação molda o comportamento dos indivíduos incutindo neles princípios e regras de conduta que determinam o modo como enfrentam o mundo. Dependendo da educação, os homens serão capazes unicamente de seguir o curso da fortuna. Mais ainda: pode levá-los identificar a "boa fortuna" com o talento, tornando-os "insolentes" no sucesso e desprezíveis no fracasso; quer dizer: pode fazer com que os homens imaginem que o êxito momentâneo é prova de sua capacidade e não fruto do acaso. Uma educação "fraca" incute nos homens ideias "vãs". Vãs são para Maquiavel ideias que levam o homem a uma atitude resignada frente ao mundo, que elevam o ideal da contemplação em lugar da ação, que cultivam o ócio em vez da virtù.

Esse argumento encontra seu fecho em outra passagem na qual Maquiavel compara a diferença de conduta entre antigos e contemporâneos, desta vez para estabelecer a causa da presença de maior amor à liberdade nos primeiros do que nos últimos:

Pensando de onde pode provir que naqueles tempos antigos os povos fossem mais amantes da liberdade do que nestes, creio que procede da mesma causa que faz os homens de hoje serem menos fortes (manco forti), o que creio estar na diferença da nossa educazione em relação à antiga, fundada na diferença entre a nossa religião e a antiga. (Discursos II,2)

A razão de os homens de hoje serem manco forti do que os antigos está na diferente educazione de uns e outros. Novamente, a debolezza dos homens provém da forma como são educados. Se os romanos eram povos fortes e corajosos não se deve a alguma qualidade peculiar à sua constituição física. Não existem povos etnicamente superiores em força e energia do que outros. Eles se distinguem entre si unicamente através de qualidades cultivadas pela educação. A virtude pode tornar um povo grande, não o acaso (fortuna). A virtude é ensinada; a fortuna é fortuita. Consequentemente, qualquer povo que tiver o mesmo apreço que os romanos pela virtude cívica pode chegar ao ponto que eles chegaram.

No fragmento acima Maquiavel se refere explicitamente à influência da religião na determinação do comportamento dos homens. A religião dos antigos fornece um "conteúdo" essencial ao processo formativo: o amor à liberdade. A fraqueza dos modernos e a exemplaridade dos antigos têm seu fundamento na diversidade radical de suas religiões e do conteúdo delas. 
Significa dizer que o mundo moderno tornou-se politicamente impotente por causa da religião cristã assim como o mundo antigo havia fundado sua exemplaridade sobre as qualidades específicas da religião pagã que lhe era própria. A primeira é mestre do ócio; a segunda da virtù.

Esta ideia é explicitada logo na sequência da passagem citada, quando Maquiavel argumenta que a liturgia do paganismo, diferente do aspecto humilde e delicado da cristã, era constituída de sacrifícios sangrentos "[...] e este espetáculo, sendo terrível, modelava os homens à sua imagem." (Discursos II,2 - grifo meu). A educação forma nos indivíduos hábitos que moldam suas condutas. A liturgia cheia de atos de ferocidade cultivava nos homens o espírito de fortaleza, de luta obstinada e de apego a este mundo, atitude bem oposta à fomentada pelo cristianismo, "[...] que glorifica mais os homens contemplativos do que os ativos". Assim, enquanto o sumo bem para o cristianismo está "[...] na humildade, na abjeção e no desprezo das coisas humanas", para os antigos está "[...] na grandeza de espírito, na fortaleza do corpo e em todas as coisas capazes de tornar os homens fortíssimos." (Discursos II,2). A consequência dessa educazione para a debolezza própria ao cristianismo é esta: "se nossa religião pede que tenhas fortaleza, quer dizer que sejas capaz de suportar e não de praticar um ato forte" (Discursos II,2). Esse modo de se comportar, conclui Maquiavel, "[...] parece que tornou o mundo debole e o converteu em presa dos homens criminosos." (Discursos II, 2).

É esse ponto que Maquiavel pretende ressaltar: as religiões não são inocentes em relação à sorte dos homens neste mundo. Elas incutem ideias que são assumidas como valores absolutos e, desta maneira, determinam o destino humano. O cristianismo, acusa Maquiavel, esvaziou do seu conteúdo real a ideia de "força" espiritualizando-a. Para o paganismo, "força" significava coragem e destemor para resistir ao inimigo, para lutar em defesa da pátria, para proteger a liberdade da cidade. Para o cristianismo, "força" é uma disposição interior para resistir aos desejos de glória e de grandeza mundana.

Quando o cristianismo esvazia o sentido originário dos valores ele condena os homens a serem vítimas de facínoras que não temem usar da força real, a força física, para submetê-los e dominá-los. A educação promovida pelo cristianismo, porque estimula a resignação, piedade e a fuga do mundo, é responsável pelo triunfo da tirania sobre a liberdade, de "[...] fazer com que não existam no mundo tantas repúblicas como antigamente e, por conseguinte, não se veja nos povos tanto amor à liberdade como naquela época." (Discursos II, 2).

Além dessa sequência de passagens em que Maquiavel se refere à educação como responsável pela debolezza da Itália daquele tempo e insiste na necessidade de espelhar-se nos exemplos dos antigos para recuperar 
a virtù perdida, apresenta outras em que ressalta a educação como força indutora de comportamentos desejáveis. A educação é uma atividade que desenvolve a virtù levando os homens à conduta adequada em relação às finalidades últimas da existência coletiva.

Uma primeira passagem nesta perspectiva é a que encontramos no começo dos Discursos. Opondo-se aos seus contemporâneos, que criticavam os tumultos que agitavam a república romana antiga, Maquiavel defende:

Não se pode chamar de modo algum com razão desordenada uma república onde existem tantos exemplos de virtù, porque os bons exemplos nascem da boa educazione, a boa educazione das boas leis e as boas leis daqueles tumultos que muitos inconsideradamente condenam. (Discursos I,4)

Maquiavel acentua o condicionamento recíproco entre a boa educação e as boas leis. "Boas leis" devem ser entendidas em sentido amplo compreendendo também as instituições estatais. A boa educação corresponde à virtude cívica que, vimos acima, diz respeito a qualidades como a simplicidade de costumes, moderação, coragem, patriotismo, disponibilidade de sacrificar-se pela pátria. Maquiavel ressalta aqui que a lei sem a virtude cívica promovida pela boa educação não produz efeito; a virtude cívica sem boas leis, por sua vez, é privada de finalidade.

Tão importante quanto o condicionamento recíproco entre educação e lei, é a circularidade entre os quatro elementos presentes no fragmento acima: exemplos, educação, leis e tumultos. O inovador no argumento de $\mathrm{Ma}$ quiavel é a vinculação do surgimento das leis aos tumultos. Este raciocínio, porém, não autoriza a concluir que haveria um nascimento espontâneo das instituições, que faria da ordem da lei a solução automática da desordem dos dissensos de uma vez para sempre. Pelo contrário, por um lado os tumultos somente são férteis pelo perigo que representam e, portanto, o Estado sempre corre o risco de se arruinar; por outro lado, é sempre possível que as dissensões acabem em lutas partidárias que visam unicamente os interesses de seus chefes, como em Florença (História de Florença VII, 1-2); ou então degenerem em guerra civil, como foi o caso de Roma em decorrência dos desdobramentos das discórdias em torno da Lei Agrária (Discursos I, 37). As dissensões não são, pois, sempre boas. A consequência dessa constatação é a exigência de que as leis tenham já modelado a desordem. Com esta posição Maquiavel consegue resolver o dilema com o qual o confrontavam os críticos dos tumultos romanos. Com efeito, se existe uma pura desordem antes da ordem instaurada pela lei, então esta é apenas contingente e a grandeza de Roma deve ser atribuída unicamente à fortuna. Maquiavel descarta, porém, decididamente este argumento: "Não posso negar que a fortuna e a milícia foram razões do império romano, mas também me parece 
que quem diz tais coisas não se apercebe de que onde há boa milícia é preciso que haja boa ordem, e raras são as vezes em que deixa de haver também boa fortuna" (Discursos I, 4). Por outro lado, Maquiavel não pode nem negar a desordem sobre a qual a ordem se apoia, nem apelar a uma ordem superior que antecederia à desordem, pois descartou a tese do primeiro legislador virtuoso, como foi Licurgo em Esparta.

A força do argumento maquiaveliano está na circularidade: os tumultos romanos não devem ser condenados como pura desordem, porque não prejudicam a virtude. Os exemplos romanos provam que a virtude nasce da boa educação, esta das boas leis que, por sua vez, se originam dos tumultos. Em outras palavras, os tumultos não engendrariam boas leis se eles mesmos já não estivessem marcados pela virtude que dispensa estas leis. A desordem permite a ordem na medida em que a ordem já sempre antecede à desordem, mas sem impedi-la.

É, pois, efetivamente um círculo que faz com que a lei, nascendo dos dissensos, seja ao mesmo tempo aquela que deve mantê-los sob vigilância, modelá-los, de sorte que permaneçam férteis; plenos desta forma de virtù que faz com que as inimizades que nascem deles produzam necessidade e não ambição. Enquanto os desejos são "coagidos pela necessidade," as inimizades permanecem sãs e culminam em leis justas. Quando, porém, se "começa a combater por ambição", prevalece o uso de meios privados no interesse de uma só pessoa, família ou facção cujo resultado final é a destruição da república.

A mesma função modeladora dos costumes é atribuída à educação em outra passagem:

No caso de homens acostumados a viver em uma cidade corrompida, onde a educazione não tenha despertado neles nenhuma virtude (bontà), é impossível que por alguma circunstância recuem em suas decisões, e para realizar sua vontade e satisfazer a perversidade de seu espírito estariam contentes em ver a ruína da sua pátria. (Discursos III,30)

No capítulo em questão, Maquiavel trata dos prejuízos que o "vício da inveja" pode causar ao bem público. Situa a educação como remédio a esse vício na medida em que é capaz de despertar alcuna bontà na mente dos homens. Quando falta essa bontà, os homens são capazes até mesmo de se alegrar ao ver a ruína de sua pátria. Chama a atenção o fato de Maquiavel conferir à educação e não à lei a força capaz de conter a derrocada do Estado. Parece que a lei só é eficaz em um Estado no qual prevalece a virtude. Quando esta se corrompe, a lei perde a capacidade de constranger a conduta dos homens.

Para Maquiavel, o ideal de perfeição do homem se alcança quando consegue colocar o interesse público acima do privado. Como a natureza pas- 
sional do homem tende ao contrário, a educação desempenha um papel fundamental no sentido de refrear os impulsos egoístas levando-o a agir pelo bem público, mesmo quando suas ações rendem glória aos outros.

Na última referência à educação presente nos Discursos, Maquiavel enfrenta a questão: como explicar a diferença entre as condutas individuais e dos grupos? Ele remete a resposta à educação:

Isto [a diferença entre as famílias] não pode provir unicamente do sangue, pois este se mistura através dos diferentes casamentos, mas é necessário que resulte da diferente educazione de uma e outra família. O que importa muito é que uma criança desde os primeiros anos comece a ouvir falar bem ou mal de uma coisa, pois necessariamente receberá disso impressões e destas extrairá regras sobre o modo de proceder durante toda a vida. (Discursos III,46)

A educação age diretamente sobre indivíduos (e não grupos). Para Pinzani (2006, p.96), "[...] obviamente Maquiavel pensa in primis nos indivíduos: é a ambição destes que deve ser contida, é o amor à pátria destes que deve ser atiçado, é o egoísmo destes que deve ser superado, é o interesse pelo bem comum destes que deve ser despertado". Contudo, alerta o intérprete, estes indivíduos não vivem isolados, mas constituem famílias e formam um povo. É como membros de grupos que apresentam características inconfundíveis que se transmitem de uma geração a outra: "parece que entre uma cidade e outra certos modos e instituições diferem, criando homens mais duros ou mais efeminados. Contudo, na mesma cidade, percebe-se que tal diferença está nas famílias, que diferem uma da outra" (Discursos III, 46). Assim, continua Maquiavel, algumas são "duras e obstinadas", outras "benignas e amantes do povo"; outras ainda "ambiciosas e inimigas da plebe".

As diferenças entre os grupos humanos (famílias e povos) são determinadas não por fatores genéticos ("de sangue"), mas pelo costume fixado através da educação. A educação forma e modela determinado conjunto de caracteres singulares que se incorporam ao modo de ser dos indivíduos que pertencem a certo agrupamento humano a ponto de se naturalizarem. Paradoxalmente, a mesma força (a educação) que modela algum agrupamento humano a ponto de parecer imutável é também aquela que possibilita romper esta cristalização. Assim, ao mesmo tempo em que tudo parece previsível, pois dá a impressão de uma determinação plena dos comportamentos humanos em virtude dos valores inculcados no indivíduo desde a mais tenra idade, constatamos igualmente que a mesma força que moldou o comportamento é capaz de transformá-lo.

Com esta constatação retornamos à questão inicial: tudo está submetido à contínua mudança. Esta é fator de desordem. A ordem brota do esforço de regulação em que a educação desempenha função decisiva. A educação 
molda comportamentos, fixa a conduta em um caráter que se constitui para o indivíduo em uma espécie de segunda natureza. No entanto, por mais estável que tudo pareça, a própria educação que, por assim dizer, "cristalizou" o comportamento numa direção, pode romper a estrutura fixada e colocá-la em movimento outra vez.

Na referência à educação em Da arte da guerra Maquiavel acentua igualmente esse aspecto da formação moral do qual a educação está encarregada. Descrevendo, pela boca de Fabrício, as qualidades do soldado, pondera:

Acima de tudo, deve-se atentar para os costumes e que ele [o soldado] seja honesto e dotado de pudor, caso contrário se escolhe um instrumento de escândalo e um princípio de corrupção. De fato, não é possível esperar que exista alguma virtù de algum modo louvável em um homem que creia numa educazione desonesta e tenha um espírito embrutecido. (Da Arte da Guerra, livro I)

O argumento de Maquiavel é de que os cidadãos são a defesa mais segura de um Estado. Por isso, sua crítica severa à utilização das forças mercenárias e auxiliares. A posição de Maquiavel favorável a um exército cidadão certamente não é bem interpretada se a reduzirmos à pura eficácia. Chabod, por exemplo, parece-nos que cai nesse equívoco, pois sustenta que Maquiavel não percebeu que, "[...] precisamente naqueles tempos, o mercenarismo militar supunha uma necessidade absoluta para os monarcas, dedicados a criar trabalhosamente os estados nacionais" (CHABOD, 1994, p.86). A insistência de Maquiavel na formação de um exército próprio decorre de sua concepção política: nenhum Estado alcança a grandeza sem um exército forte constituído a partir de seus cidadãos. A formação de um exército popular pode gerar nos cidadãos um conjunto virtudes essenciais à vida política: patriotismo, sentido de responsabilidade, solidariedade. Enfim, a educação para a vida militar forma no fim das contas o "bom cidadão": renúncia ao interesse próprio em favor do público, espírito de sacrifício, inclusive de morrer se necessário, moderação e cultivo de uma vida simples e sem luxo, sem ócio e costumes corrompidos.

Finalmente, a última das onze referências na obra de Maquiavel à educazione que nos falta comentar, presente no Capítulo - Da Ambição, volta o tema da força modeladora. Dessa vez, é conferida à educação uma energia capaz de suprir aquilo em que a natureza é falha:

E se alguém culpasse a natureza/ porque na Itália, tão aflita e cansada,/ não nascem pessoas tão corajosas e obstinadas,/ digo que isto não desculpa e livra/ a nossa covardia, porque a educazione pode suprir/ onde a natureza falha. (I CapitoliDell'Ambizione, vs 109-114) 
Dentre todos os fragmentos analisados, este parece o mais expressivo em relação à capacidade modeladora da educação, inclusive em relação à natureza. Maquiavel sugere que ela tem a possibilidade de "preencher" as lacunas deixadas em aberto pela natureza. Esta última deixa de ser uma força inexorável para se transformar em matéria moldável pela educação. A natureza pode ser recriada, ao ser moldada pela educação, de acordo com as finalidades colocadas pela coletividade. Nada está definitivamente dado, sequer o que parece ser assim: a natureza.

Com esta posição, o pensador florentino dirige uma crítica severa aos seus conterrâneos, que pretendem desculpar-se pela divisão e desordem reinantes apelando a fatores que parecem incontroláveis como a natureza. O raciocínio dos conterrâneos de Maquiavel parece ser este: se a Itália está nesta situação caótica é porque foi preterida por alguma força sobrenatural em relação às demais nações fazendo com que não surjam homens "corajosos e obstinados"; a natureza foi ingrata com eles. Maquiavel, opondo-se a esta visão fatalista das coisas, faz recair toda responsabilidade sobre os próprios italianos. Nada "desculpa e livra nossa covardia": a divisão e desordem reinantes são fruto de decisões políticas equivocadas e não de uma natureza ingrata. "Coragem e obstinação" não são presentes dos céus. São frutos de uma educação para a cidadania que cultiva nos homens as virtudes imprescindíveis para a vida política. Estas qualidades não são boas em si ou porque podem ser instrumentos para o aperfeiçoamento moral dos indivíduos, mas porque fazem com que os homens sejam capazes de assumir a vida política como tarefa sua.

Podemos dizer que as virtudes cívicas cultivadas pela educação fazem de alguém um bom cidadão e não um homem bom. Um "bom cidadão", para Maquiavel, é alguém com hábitos de vida simples, coragem, patriotismo, disposição ao sacrifício pelo bem comum, etc. Um "homem bom", por sua vez, é aquele que possui um conjunto de qualidades morais em grau de excelência, tais como honestidade, senso de justiça, retidão de caráter, piedade, etc. Não há relação necessária entre as duas "bondades": é possível ser honesto, íntegro, justo, fiel e, no entanto, ser incapaz de sacrificar-se pelo bem público, de assumir os encargos públicos como tarefa sua. Se Maquiavel se interessa pelo "bom cidadão" e não pelo "homem bom" não é porque considera irrelevante o último, e sim porque, como pensador político e não teórico da moral, se preocupa com as condições de possibilidade para o estabelecimento de uma república estável e duradoura. As virtudes morais não têm valor em si, mas são relevantes na medida em que contribuem ou prejudicam a formação do bom cidadão.

Encaminhando nossa reflexão para a conclusão, podemos dizer que Maquiavel não refletiu sobre a educação na perspectiva de um "pedagogo" que oferece uma nova "teoria da educação" aos seus leitores. Escreveu 
numa perspectiva renascentista, que afirma o homem ativo e não o contemplativo como era a perspectiva dominante na tradição medieval-cristã. A partir de suas reflexões emerge um posicionamento que, mesmo não constituindo uma "pedagogia", oferece um conhecimento e observação dos costumes da vida social que revela uma clara ideia da educação como método próprio para assegurar a formação e o desenvolvimento físico, intelectual e moral imprescindíveis para assumir a vida política como tarefa de cada um.

Primeiramente, entende a educação como aquilo de que é permeada a matéria social. A educação é o condicionamento psicológico e moral que determina a vida humana individual e coletiva. É o conjunto de pressupostos teóricos, de juízos e convicções de toda ordem que regulam a vida dos cidadãos. Ela "forma" o cidadão ao inculcar nele a virtù cívica: o amor à pátria, a dedicação ao bem público, a subordinação do bem privado ao bem público. Está explícita aqui uma moralidade: Maquiavel condena como vício o ócio, a inveja, a ingratidão, o egoísmo e tudo aquilo que impede o homem de engajar-se na defesa da liberdade como bem coletivo. Importante frisar que estas qualidades são importantes porque contribuem para a estabilidade e permanência da república e não porque são atributos bons por expressarem a perfeição moral de um indivíduo.

Um segundo aspecto refere-se ao caráter intrinsecamente mutável de todas as coisas e a tarefa da educação na modelação do comportamento humano. A ação política, por estar inscrita no tempo, precisa "inventar" seu que fazer no instante mesmo em que se efetiva. Não existe teleologia inscrita na história. Como proceder para que este agir não seja destituído de rumo? Como é possível conhecer o "curso das coisas"? Como acertar nas decisões políticas? A condição na qual o homem de ação se encontra, no campo político, requer dele a faculdade não somente de "saber", mas de "saber prever" e, a partir destes dois "saberes", a capacidade de "saber-fazer", isto é, de estabelecer estratégias de ação voltadas ao êxito. A educação vem em socorro dessa necessidade. A história ensina que o comportamento humano é determinado por condutas que se repetem ao longo dos tempos, produzidas pelo condicionamento promovido pela educação. A educação molda o comportamento ao estimular os indivíduos a praticar valores e princípios. O estudo da história torna-se vital para conhecer esses modos de vida que se repetem, pois possibilita a previsão e a antecipação. É a razão pela qual Maquiavel insiste na necessidade da imitação dos antigos, pois neles estão modelos de conduta que se reproduzem na história e que, uma vez conhecidos, prestam-se para formular modos de ação voltados ao êxito.

Enfim, Maquiavel estabelece uma relação muito estreita entre a moralidade cívica e a vida política saudável: sem bons costumes não existem Estados solidamente instituídos. Por esta razão, quando os costumes se cor- 
rompem segue inevitavelmente a decadência política. Desta maneira, a moralidade dos cidadãos, compreendida como o cultivo das virtudes cívicas, não é um fator entre outros para a continuidade dos Estados, mas é o fator por excelência. É mais importante do que as próprias leis, pois onde falta a virtude cívica, as leis se mostram impotentes para restaurar a vida política.

AMES, José Luiz. Machiavelli and the education: the formation of the good citizen. Trans/Form/Ação. (São Paulo), v.31(2), 2008, p. 137-152.

- ABSTRACT: Machiavelli is commonly known by a political theory associated to his name: "machiavellism". The initial effort of the article is to take apart Machiavellian thought from such a conception. After this it tries a detailed analysis of all occurrences of the term "education", which amounts to eleven times in his work. The hypothesis by which our reflexion is guided is that education is conceived by Machiavelli as a force addressed to control the desire's as well as the nature's inherent movement disorder, preventing the deleterious effects of the first on the political life. Due to education the human being is able to know the "nature of things", i.e., to know what things "always were", and, through such knowledge, to anticipate to the "course of the things ordered by the heaven". Finally, we will try to demonstrate that for Machiavelli education provides the adaptation of the individuals behaviour in such a way that it is possible to redirect the course of things for a coherent order in regard to the collective good.

- KEYWORDS: Machiavelli; education; citizenship; politics; ethics.

\section{Referências bibliográficas}

CASSIRER, Ernst. El Mito del Estado. México: Fondo de Cultura Económica, 1992.

CHABOD, Francesco. Escritos sobre Maquiavelo. Tradução de Rodrigo Ruza. 2.ed. México: Fondo de Cultura Económica, 1994.

MACHIAVELLI, Niccolò. Opere di Niccolò Machiavelli. Torino: UTET, 1996. v. 1 e 2.

MACHIAVELLI, Niccolò. I Capitoli. Opere di Niccolò Machiavelli. v. 4. Torino, UTET, 1996.

MURALT, Leonard von. Machiavellis Staatsgedanke. Basel: Benno Schwabe, 1945.

PINZANI, Alessandro. Ghirlande di fiori e catene di ferro: Istituzione e virtù politiche in Machiavelli, Hobbes, Rousseau e Kant. Firenze: Le Lettere, 2006.

RENAUDET, Augustin. Machiavel. Paris: Gallimard, 1942.

SKINNER, Quentin. As fundações do pensamento político moderno. São Paulo: Cia. das Letras, 1996. 